\title{
Shared Leadership and Innovation: The Role of Vertical Leadership and Employee Integrity
}

\author{
Julia E. Hoch
}

Published online: 25 September 2012

(C) Springer Science+Business Media, LLC 2012

\begin{abstract}
Purpose The purpose of this study was to investigate the relationship between shared leadership, as a collective within-team leadership, and innovative behavior, as well as antecedents of shared leadership in terms of team composition and vertical transformational and empowering leadership.

Design/Methodology/Approach Data were obtained from a field sample of 43 work teams, comprising 184 team members and their team leaders from two different companies. Team leaders rated the teams' innovative behavior and their own leadership; team members provided information on their personality and their teams' shared leadership.

Findings Shared and vertical leadership, but not team composition, was positively associated with the teams' level of innovative behavior. Vertical transformational and empowering leadership and team composition in terms of integrity were positively related to shared leadership.

Implications Understanding how organizations can enhance their own innovation is crucial for the organizations' competitiveness and survival. Furthermore, the increasing prevalence of teams, as work arrangements in organizations, raises the question of how to successfully manage teams. This study suggests that organizations should facilitate shared leadership which has a positive association with innovation.
\end{abstract}

J. E. Hoch $(\square)$

School of Human Resources and Labor Relations,

Michigan State University, 412 South Kedzie,

East Lansing, MI 48824, USA

e-mail: hochj@msu.edu
Originality/Value This is one of the first studies to provide evidence of the relationship between shared leadership and innovative behavior, an important organizational outcome. In addition, the study explores two important predictors of shared leadership, transformational and empowering leadership, and the team composition in respect to integrity. While researchers and practitioners agree that shared leadership is important, knowledge on its antecedents is still in its infancy.

Keywords Shared leadership - Innovative behavior . Team management $\cdot$ Leadership $\cdot$ Antecedents

The increased use of teams as an approach to accomplish work in organizations has resulted in new challenges with respect to management of these structures. One approach to team management has been shared leadership, which is "a dynamic interactive influence process among individuals in groups for which the objective is to lead one another to the achievement of group or organizational goals or both" (Pearce and Conger 2003, p. 1). Shared leadership can be described as internal, informal team leadership (Morgeson et al. 2010) and requires the distribution of leadership influence across different individuals (e.g., Carson et al. 2007). In contrast to vertical leadership, which describes formal and hierarchical top-down leadership of external team leaders (Carson et al. 2007; Ensley at al. 2003; Morgeson et al. 2010), relatively little is known regarding antecedents and outcomes of shared leadership.

A review of the literature indicates that shared leadership has been demonstrated to enhance team and organizational performance and team effectiveness (Ensley et al. 2006; Hmieleski et al. 2011; Pearce et al. 2004). As a leadership approach, shared leadership is not mutually 
exclusive to other leadership forms and behaviors, but can be engaged in simultaneously, with other leadership approaches, such as vertical leadership. Shared leadership has been shown to exceed effects of vertical leadership in predicting team outcomes (Pearce and Sims 2002). So far, beyond shared leaderships' impact of team performance, researchers have investigated few other outcome variables.

As shared leadership emerges mainly in team-based work structures and is appropriate for dealing with changes and competitive environments (Pearce 2004; Pearce and Manz 2005) one possible outcome of shared leadership is team innovative behavior (West and Farr 1989). Innovation is important as it influences organizational capability to adapt to change and remain competitive in changing surroundings (West and Farr 1989). We expect that shared leadership will play a role in facilitating the teams' ability to adapt to change and thus will be associated with team innovative behavior. Therefore, an objective of this study is to test whether innovation represents an outcome of shared leadership.

As shared leadership is viewed as a key to organizational innovation, the question arises how the development of shared leadership can be facilitated. So far, there is little research about important antecedents of shared leadership (e.g., Mayo et al. 2003; Mehra et al. 2006). Generally, at least two types of antecedents of shared leadership can be distinguished. First is the vertical leadership by the external team leader. Second is the team composition with respect to the attributes of the team members. While this has been theoretically argued (e.g., Cox et al. 2003; Pearce and Sims 2000), scant empirical research has simultaneously addressed the two areas of antecedents of shared leadership (for an exception, see Carson et al. 2007). Specifically, vertical team leadership in terms of transformational and empowering leadership is considered to predict shared leadership, as it may lead to the development of a collective vision, as well as teams' self-management skills (both likely predictors of shared leadership). Team composition with regard to team members attributes includes integrity, comprising responsibility and trustworthiness; the degree to which team members engage in shared leadership may be impacted by personality factors that influence preferences for loyalty, transparency and fairness, or equality, rather than promoting one's self-interest in achieving personal goals. Consequently, in addition to vertical transformational and empowering leadership, we investigate team member's integrity as antecedent of shared leadership.

Together, we present and test an input-process output model (IPO) (Hackman 1987; Illgen et al. 2005; McGrath 1991), following and extending the assumptions of nomological network approach (Cronbach and Meehl 1955) on antecedents and outcomes of shared leadership. Vertical transformational and empowering leadership and team member integrity are positioned as antecedents of shared leadership and innovation is portrayed as the outcome of shared leadership. Shared leadership is portrayed as an indirect effect (Mathieu and Taylor 2006) between the antecedents and outcome. We test the indirect influencing role of shared leadership as a pathway in conveying the impact of integrity and vertical transformational and empowering leadership on team innovative behavior in a sample of 43 face-to-face work teams.

\section{Theoretical Background}

\section{Nomological Network on Shared Leadership}

Along with the increased use of teams in organizations, the question naturally arises regarding what forms of management are best suited for these structures and will promote the attainment of team performance outcomes such as innovation (Currie et al. 2009; Fry and Kriger 2009; Stewart and Manz 1995). Our belief is that shared leadership, in which the team members lead each other to the achievement of particular goals (Chou et al. 2008), represents an approach that may contribute to team innovative behavior. While increasingly research has addressed the impact of shared leadership with respect to predicting team and organizational performance in different organizational settings (Ensley et al. 2006; Pearce and Sims 2002), limited empirical research has investigated the impact of shared leadership on team innovation.

Furthermore, only limited research has addressed the impact of antecedents of shared leadership (e.g., Cox et al. 2003; Pearce and Sims 2000). The goal of this study was to extend the prior literature on shared leadership by investigating both antecedents and outcomes of shared leadership. Precisely, while the literature on shared leadership as well as its antecedents and outcomes is still scarce (e.g., Cox et al. 2003; Pearce and Sims 2000), with respect to the supervisors and team composition at least two different types of antecedents have been proposed. As a basis for our model development, following and extending the assumptions of nomological network approach (Cronbach and Meehl 1955), we present and test an IPO model (Hackman 1987; Illgen et al. 2005; McGrath 1991) on antecedents and outcomes of shared leadership. We present our model in Fig. 1. Shared leadership is portrayed as an indirect effect (Mathieu and Taylor 2006) explaining the relationship between vertical transformational and empowering leadership and team composition with innovation as a team outcome. 
Fig. 1 Input-Process-Output Model of Shared Leadership predicting Innovation, Vertical Leadership and Employee Integrity predicting Shared Leadership

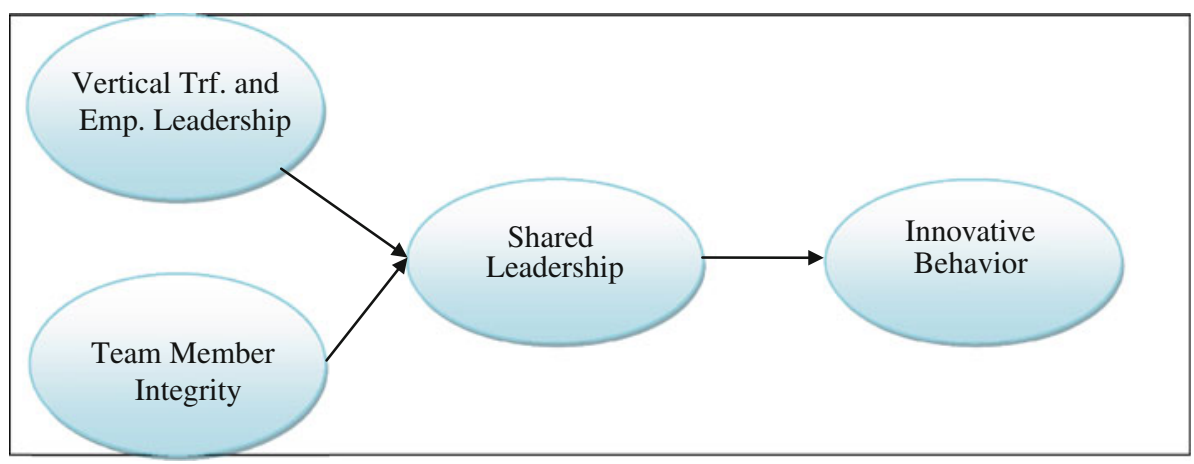

Shared Leadership and Team Innovation

Shared leadership reflects a situation where multiple team members engage in leadership and is characterized by collaborative decision-making and shared responsibility for outcomes. It has been described as a mutual influence process carried on by members of a team where they lead each other toward the achievement of goals (Day et al. 2004; Pearce and Conger 2003). Shared leadership is conceived as a property of the group as a whole, "as a set of functions which must be carried out by the group" (Gibb 1954 , p. 884) and it is generally characterized by the spreading of leadership to multiple or all, rather than only a few, team members. This was for example noted by Ensley et al. (2006: 200), who described shared leadership as a "team process where leadership is carried out by the team as a whole, rather than solely by a single designated individual" (Ensley et al. 2006, p. 220).

Carson et al. (2007, p. 1218) defined shared leadership as an "emergent team property that results from the distribution of leadership influence across multiple team members." A key aspect of shared leadership is that the team members share their distinct knowledge and it is through knowledge sharing that team members access and build on each other's ideas. Carson et al. (2007) state: “...shared leadership can provide organizations with competitive advantage through...organizational resources brought to bear on complex tasks, in openness to reciprocal influence from others, and in the sharing of information" (Carson et al. 2007, p. 1217). Different team members engage in shared leadership and their leadership works together simultaneously or sequentially, additive or in a compensatory way, across the different stages of a project or the team life cycle.

Shared leadership describes an informal, internal team leadership behavior by the team members (Morgeson et al. 2010). As such, shared leadership can be contrasted with the external and formal team leadership by the sponsor, coach or team advisor, the external and informal leadership by the mentor and team champion, as well as the internal and formal leadership provided by the project leader or manager. Team members can informally engage in a number of different internal team leadership behaviors (for a complete review, see Morgeson et al. 2010, p. 10). Some of these behaviors are: establishing expectations and defining a collective mission, creating a supportive climate, sense making, structuring the team task, providing feedback, and problem solving. Finally, providing resources, as well as encouraging team self-management, are important internal informal leadership functions.

\section{Innovation}

Organizational change and adaptation to new and fastchanging surroundings, conversely, is crucial for today's organizations to remain competitive. Complex, knowledgebased work, and adaptation to changing surroundings, fast decision-making, and other proactive practices often require teams, which are increasingly being used in organizations (Illgen et al. 2005; Kozlowski and Bell 2003; Liden and Antonakis 2009; Stewart and Manz 1995). Furthermore, to remain competitive, innovation is widely viewed as essential for success and long-term survival (Amabile 1988; Ancona and Caldwell 1992; Kanter 1988; Mumford 2000). Team innovation has been described as the creation of new and useful, or functional ideas, and their application in organizational settings. Innovation benefits the organization and innovative teams and organizations also tend to achieve higher levels of performance (Balkin et al. 2001; West and Farr 1989).

Researchers have described innovation in organizations as a complex process that comprises at least two different stages, namely the generation of new and functional ideas (also referred to as "creativity"), and their implementation in the organization (Amabile 1996; Huelsheger et al. 2009; West 1990). With regard to the second stage the two phases of idea promotion and idea realization have been identified. With regard to the overall team innovation process and its stages, different individuals can perform different behaviors at different stages of the team innovation process. 
Generally, team innovation has been shown to relate to a number of other group processes (Janssen 2000; Janssen et al. 2004; Van der Vegt and Janssen 2003; West and Farr 1989). Findings from a recent meta-analysis (Huelsheger et al. 2009) summarized the research on antecedents of team innovation. Huelsheger et al.'s (2009) meta-analysis points out the importance of team-level variables such as team cohesion, conflict, vision, and support for innovation as antecedents for innovation in teams. Precisely, Huelsheger et al. (2009) found a stronger impact of process-related variables and behaviors, such as vision, task orientation, and external communication, as antecedents of team innovation, and weaker effects of the impact of team composition and structure. Accordingly, with regard to shared leadership, we expect that the shared leadership behaviors may be more important than the team composition, when it comes to predicting team innovation. Furthermore, in line with this, it has been shown that external team leaders can promote innovation, directly and indirectly, for example, by implementing a climate that helps the development, and is supportive, of new ideas (Amabile et al. 2004; Edmondson 1999; Choi and Chang 2009; Hunter and Cushenbery 2011) or by being indirectly supportive of those who implement new ideas with a focus on the organization, rather their own individual goals.

The first stage of the innovation process, creativity-or idea generation-describes the creation of new ideas, techniques or instruments as a component of innovation (Janssen 2000; Kanter 1988; Huelsheger et al. 2009). Through the process of information sharing we assume that shared leadership will lead to the increased generation of new ideas and therefore enhance creativity. Implicit in this assumption is the notion that more ideas will also lead to better ideas. But an increased number of ideas could possibly lead to a lot of bad ideas. ${ }^{1}$ What is needed is for the team to critically discuss and elaborate on the ideas generated and this process of sharing ideas may lead to greater creativity. Generally, within teams, new and creative ideas are more likely to develop under supportive leadership or in a climate of support (e.g., Amabile et al. 2004; Hunter and Cushenbery 2011). Furthermore, the development of new and creative ideas may also correlate with perceived self-efficacy (e.g., Bandura 1997) and group potency (e.g., Guzzo et al. 1993) as it needs a critical reflection of the "status quo" (one would have to find out what is not going well before finding out ways to improve things) in the team.

With respect to idea generation, shared leadership might lead to processes of knowledge sharing of "distinct knowledge backgrounds" by the team members and may "...provide organizations with competitive advantage"

\footnotetext{
1 The author expresses appreciation to an anonymous reviewer for this idea.
}

(Carson et al. 2007, p. 1217). In other words, if team members have diverse knowledge and information and these will be shared, this will lead to a competitive advantage for the team and for the complex task of innovation. Information sharing will be encouraged by a supportive social climate and collective goals (Morgeson et al. 2010).

Under higher levels of shared leadership, team members are more likely to contribute ideas and make their unique information accessible to the other team members. This is beneficial for two reasons. First, as the team members sharing the lead will contribute their ideas, the team as a whole will possess more ideas and develop higher levels of creativity and idea generation. Second, as team members present information, the team members might also build upon their ideas. This may be reflected in informal internal leadership behaviors of planning and providing feedback, as well as sense making and developing problem solutions (Morgeson et al. 2010). When it comes to shared leadership this will lead to higher levels of creativity and idea generation.

The second stage of the implementation of new ideas comprises idea promotion, which involves mobilizing support for innovative ideas and acquiring approval for those ideas within the organization, and idea realization, which involves transforming innovative ideas into useful applications, and acquiring the support necessary for the new idea (Janssen 2000; Kanter 1988; Scott and Bruce 1994). Idea promotion has been related to group processes as well (for overview, Huelsheger et al. 2009). Precisely, it might be through their stronger ties, team identification, and focus on the collective goal(s) (Kouzes and Posner 2009) that team members might more likely engage in developing each other (i.e., shared collective empowering and self-leadership; Pearce and Manz 2005) and leading each other in reaching their collective goals. Thus, shared and collective forms of team empowerment will likely encourage team innovation (Spreitzer et al. 1999).

Next, internal informal leadership by team members aimed at the promotion of each other's respective ideas is more likely when the team is working under a shared and collective vision, and when the team is working toward the common goals (e.g., Carson et al. 2007; Morgeson et al. 2010). Thus, informal internal leadership (Morgeson et al. 2010, p. 10) might also be helpful in developing a climate of social support and shared mission. Teams that are higher in collective efficacy and group potency are more likely to support each other's ideas (Solansky 2008). Based on Morgeson et al. (2010), these functions may be reflected in such as problem solving and providing resources, as well as developing a climate of mutual respect and support.

Idea realization involves transforming innovative ideas into useful applications in the wider organization (e.g., 
Janssen et al. 2004). Collective goals (e.g., Kouzes and Posner 2009) will be more likely achieved, if a unified team, rather than a group of several scattered individuals, jointly pursues the goals, rather than each pursuing their own individual goals (Pearce et al. 2008). If the team works together and shares resources (e.g., Morgeson et al. 2010) the team, as a whole, will be more effective. In regards to idea realization, mutually providing each other with feedback and resources, training and developing and encouraging the teams' self-development, are expected to be helpful. Consequently, training, development, and encouraging team members to work together toward problem solving and achieving the team goals are important internal leadership functions (e.g., Morgeson et al. 2010). The realization of ideas that are pursued by a group are more likely to succeed, than an idea that is held by a single individual, as the team is more likely to have a larger influence network.

Together we expect that shared leadership will lead to higher levels of team innovation. Under lower levels of shared leadership, conversely, lower team innovation will result. Therefore, we propose the following:

Hypothesis 1 Shared leadership will be associated with innovative behavior in teams.

Antecedents of Shared Leadership, Shared Leadership as Mediator

While shared leadership might enhance team innovation and foster organizational competitiveness, the question arises regarding how shared leadership can be facilitated. A criticism in the literature is that little research has empirically addressed antecedents of shared leadership (Carson et al. 2007; Cox et al. 2003; Pearce and Conger 2003). We expect that both team leader and team member factors will affect the occurrence of shared leadership. Drawing from nomological network (Cronbach and Meehl 1955) and IPO model approach (Hackman 1987; Illgen et al. 2005; McGrath 1991), we conceptualize shared leadership as a mediating variable, indirectly affecting the relationship between vertical leadership and team composition on team innovation.

\section{Team Leaders' Vertical Transformational and Empowering Leadership and Shared Leadership}

Vertical leadership describes the leadership by the external or internal, formally appointed team leader (Ensley et al. 2006; Morgeson et al. 2010). Two important vertical leadership behaviors are empowering leadership and transformational leadership (e.g., Pearce and Sims 2002). A central aspect of vertical leadership is that it is a formally recognized leadership role. As such, vertical transformational and empowering leadership are not restricted to the team leader having to be external to the team, it can also occur with regard to an internal, appointed team leader. This is contrasted with internally and informally shared transformational and empowering leadership by the team members. As one group of factors that may enhance shared leadership, vertical transformational and empowering leadership behaviors have been discussed. Vertical transformational and empowering team leaders can encourage shared leadership (Carson et al. 2007; Pearce et al. 2008).

Several theoretical frameworks (e.g., Cox et al. 2003; Pearce and Sims 2000) conceptualized vertical transformational and empowering leadership as an antecedent of shared leadership. For example, Pearce et al. (2008) argued that vertical transformational and empowering leadership exhibits behaviors that empower employees and encourages shared leadership. Similarly, Carson et al. (2007) found that external coaching is an important predictor of shared leadership. However, although some studies have supported this link (e.g., Pearce et al. 2008), too often in this research the two forms of leadership are juxtaposed (e.g., Pearce and Sims 2002). The two behaviors of vertical leadership that are expected to influence shared leadership are the leaders' empowering and transformational leadership.

Empowering leadership may directly or indirectly influence shared leadership, for example by fostering the development of team member individual self-leadership and self-efficacy (Bandura 1997; Manz and Sims 1991; Pearce and Manz 2005). Manz and Sims (1987), in their seminal work on self-managing teams, stated that traditional participative leadership differs from empowering leadership as participation relates to the delegation of decision authority, whereas empowering fosters the development of the employees.

A further distinction that is important is the one between individual and team empowerment. Empowering of individuals can be conducted through developing their selfmanagement skills. Pearce and Sims (2002) suggested that behaviors such as encouraging-independent action, opportunity-thinking, self-development, or self-reward are likely to develop individual followers. Team empowering, conversely, has been defined as "increased task motivation that is due to team members' collective, positive assessments of their organizational tasks" (Kirkman et al. 2004: 176). Empowering of teams can be conducted by fostering team collaboration, working together as a team, and encouraging team members to sharing the lead with others who are members in the same team. Accordingly, empowering leadership may directly create shared leadership (Ensley et al. 2006; Neck and Houghton 2006; Pearce and Sims 2002), or it may indirectly influence shared leadership, i.e., 
by fostering the development of the team member's individual self-leadership skills (Manz 1986) and self-efficacy (Bandura 1997). Self-leadership skills have been argued to in turn develop shared leadership skills (e.g., Pearce and Manz 2005). In total, we expect that vertical empowering leadership, comprising individual and team empowering and participative leadership will foster shared leadership development in teams.

A second vertical or hierarchical external team leadership behavior that might encourage shared leadership development is transformational leadership. Transformational leadership has been shown to be able to motivate team members to go beyond self-interest and focus on group (or organizational) goals (Currie and Lockett 2007; House and Baetz 1979). Transformational leadership leads to increases in a shared vision among team members (Kouzes and Posner 2009), which might be important predictors to developing shared leadership. A shared vision, replacing individual, self-centered goals with the focus on the "team" is an important antecedent for shared leadership. A shared vision and focus on "team" goals might be important antecedents of shared leadership development. As Pearce and Conger (2003, p. 1) argue, the objective of shared leadership is for the team members: "...to lead one another to the achievement of group or organizational goals or both" (Pearce and Conger 2003, p. 1).

Likewise, it has been shown that charismatic leaders enhance positive team processes such as collective efficacy or cooperation (Pillai and Williams 2004), organizational citizenship behavior, and a sense of belongingness among team members (e.g., De Cremer and van Knippenberg 2002). Effective collaboration and coordination among team members, according to Morgeson et al. (2010) is one of the cores to shared leadership, or informal indirect leadership by the employees. As transformational leadership, consequently, has been shown to enhance these, it is likely that charismatic leadership behaviors will be related to the development of shared leadership.

Finally, transformational leadership has been found to be positively related to team reflexivity, which is similar to group learning (Schippers et al. 2008). Furthermore, the cognitive processes of information elaboration and mapping the distinct knowledge backgrounds are, according to Carson et al. (2007 see above), important components of shared leadership. In line with that, shared leadership has been shown to positively relate to transactive memory systems (e.g., Solansky 2008). Together, beyond empowering leadership (Pearce et al. 2008), transformational leadership behaviors are expected to facilitate the development of shared leadership. We therefore propose the following:
Hypothesis 2a Vertical empowering and transformational leadership will be positively associated with shared leadership.

Indirect Role of Shared Leadership in the Vertical Transformational and Empowering Leadership-Innovation Relationship

Vertical leadership by the external team leader, such as transformational leadership, has been shown to relate to innovation, at the team and organization level (e.g., Choi and Chang 2009; Garcia-Mortales et al. 2008; Jung et al. 2003; Shin and Zhou 2003; Woodman et al. 1993). Beyond transformational leadership, innovation can also be facilitated and supported indirectly by the leader (Amabile et al. 2004; Hunter and Cushenbery 2011), such as by developing a climate of innovation and support for new ideas, or more broadly, by implementing a climate that helps the development of new ideas.

Examples where vertical transformational leadership has been shown to impact collective team outcomes, through collective within-team behaviors, include studies that have demonstrated that transformational leadership behaviors increase work outcomes via intrinsic motivation and goal commitment (Piccolo and Colquitt 2006), trust and value congruence (Jung and Avolio 2000), and team potency and cohesion (Bass et al. 2003). The same might be true with regard to the impact of vertical transformational leadership on team innovation, through the processes of shared leadership.

Consequently, regarding team innovation as a desired outcome (i.e., within a team context), it will more likely be the team members and not necessarily the leader, who innovate. Accordingly, in this model, as displayed in Fig. 1, the team members, rather than the vertical transformational and empowering leadership, directly impact team innovative behavior. By impacting team members' attitudes and behaviors, and by facilitating shared leadership, however, the vertical transformational and empowering leader might indirectly contribute to innovation (e.g., Amabile et al. 2004; Hunter and Cushenbery 2011). In showing the above leadership behavior and in encouraging shared leadership, vertical transformational and empowering leadership may develop an overall organizational and team climate, where suggestions for improvement are welcome, support for them and team members is expected, and innovation is appreciated. This climate would also indicate that the goals of the organization are valued and have priority, toward individuals' own goals.

Consequently, we expect the relationship between vertical transformational and empowering leadership and innovation to be indirect and due to the impact of vertical 
transformational and empowering leadership on shared leadership. The indirect effect we expect for vertical transformational and empowering leadership through shared leadership on innovation is portrayed in Fig. 1 and we propose the following:

Hypothesis 2b Shared leadership will indirectly influence the relationship between vertical transformational and empowering leadership and team innovative behavior.

\section{Team Member Integrity and Shared Leadership}

Team member personality factors may represent additional antecedents of shared leadership because of their influence on attitudes and behavior. The degree to which team members engage in shared leadership may be impacted by personality factors that impact preferences for loyalty, transparency and fairness, or equality, rather than promoting one's self-interest in achieving personal goals. In line with this thought, team member integrity has received significant attention with meta-analytic results showing that employees' team member integrity correlates with high work performance (Dineen et al. 2006; Ones et al. 1993; Van Iddekinge et al. 2011, in press). Integrity also has been demonstrated to be an antecedent of successful leadership (De Hoogh et al. 2005; Spangler and House 1991; Winter 2007).

When it comes to team composition, different traits have been investigated (Harrison and Klein 2007). For example, research on the Big Five has shown that these are typically positively related to team performance (Barrick et al. 2001, 1998). Thereby, while there are several studies showing that the variance with respect to a particular trait is important, the majority of studies still consider the mean score as important. For example, while extroversion is considered more positive if it is heterogeneously, rather than homogeneously, distributed across the team (e.g., Barrick et al. 1998), in most cases, the relationship is still additive (Neubert and Taggar 2004).

Exceeding the Big Five, motive dispositions have been examined to predict leadership skills. Motive dispositions are defined as a relatively enduring preference for a broadly defined class of affectively tinged goals that energize and direct a person's behavior outside of his or her conscious awareness (McClelland and Boyatzis 1982). The three big motive dispositions are power, achievement, and affiliation orientation (McClelland 1985). With regard to leadership, the three motive dispositions have been shown to display distinct effects. With regard to their leadership motive profile (LMP), for example, McClelland and Burnham (1976, 2003) found that leaders reported higher work morale who possessed high achievement motivation, low affiliation motivation, and a high concern for the moral exercise of power (which they labeled LMP). A number of historical (McClelland and Burnham 1976; Spangler and House 1991) and more recent (De Hoogh et al. 2005; De Hoogh and Den Hartog 2008) studies replicated these findings. For example, Spangler and House (1991), counted the number of "not's" in presidential speeches, and found that elements of the LMP predicted perceived greatness and social performance among US presidents. Socially responsibility leaders were found to have higher levels of performance and team effectiveness in managerial and nonprofit work settings (De Hoogh et al. 2005; De Hoogh and Den Hartog 2008).

Power motivation refers to the desire to control and influence others rather than being controlled by them. (Veroff and Veroff 1972; Winter 1973). Researchers distinguish between socialized and personalized power motivation (Winter 2007), with the socialized power motivation being a more effective and stronger predictor of (team) performance. Socially responsible leaders also caused fewer wars (De Hoogh et al. 2005; Spangler and House 1991; Winter 2007).

Social responsibility, or integrity, according to Winter and Barenbaum (1985) can comprise the two factors of (1) reliability and (2) trustworthiness. Integrity has been used interchangeably with socialized responsibility and trustworthiness. A different group of studies has referred to integrity, similar to socialized power motivation, as comprising the two facets of responsibility and trustworthiness (e.g., Ones et al. 1993; Van Iddekinge et al. 2011). We believe that social responsibility or integrity, at the team level (e.g., Taggar et al. 1999) is related to shared leadership for several reasons. First, socially responsibility means being reliable. Reliability is important for being predictable in the long run. Team processes need to be considered in a longitudinal sense. In the long run, teams need to be reliable and make sure that those who contribute and share information will be rewarded in return. Shared leadership will thus benefit from higher levels of integrity, because it includes higher levels of reliability among the team members. If team members are more reliable, they are more likely to reciprocate and less likely to abuse each other (e.g., engaging in social loafing, e.g., Karau and Williams 1993) and this will help shared leadership to develop.

Second, being high in integrity means being trustworthy. Developing shared leadership requires that information be exchanged freely and transparently, which also allows improving each other's ideas. Generally, the sharing of team members' unique and disjunctive (non-overlapping) knowledge (e.g., Carson et al. 2007) will be more likely in teams where members are higher in trustworthiness. Conversely, sharing of information is unlikely without trusting in other team members' integrity. Thereby, team members 
that are higher in integrity themselves are also more likely to trust others. Trustworthiness, as aspect of integrity, will therefore be related to shared leadership. Together, integrity, or socialized power motivation is expected to predict shared leadership, based on the idea of a shift in reference from the "I" to the "we" (Chan 1998). Development of shared leadership with a history of kept promises is more likely.

According to their personality disposition, members high in integrity are more likely to share the lead. Based on the above, we expect that the average level of integrity, perceived by team members for their teams, is an important antecedent of shared leadership, as displayed in Fig. 1. Thus, we propose the following:

Hypothesis 3a Team member integrity will be positively associated with shared leadership.

\section{Indirect Role of shared leadership in the Integrity- Innovation Relationship}

Researchers have increasingly and frequently argued that personality research would benefit from investigating more mediating variables (e.g., Hogan et al. 1994; Witt et al. 2002). Integrity, as a trait or attitude, will not predict anything unless it is reflected in certain kinds of (team) behaviors that will lead to certain outcomes (e.g., information sharing, trusting each other; Carson et al. 2007; Hogan et al. 1994). Consequently, we expect that integrity has to be expressed in concrete collective team work behavior, such as shared leadership, to be visible, and subsequently achieve positive organizational results, for example innovative behavior.

Leader personality is expected to predict leadership behavior, which in turn is expected to influence team performance (Hogan et al. 1994). Leadership is conceptualized as a mediating variable explaining the relationship between input factors of personality and outcomes of performance. In the same way, applying Chan's (1998) reference shift or direct consensus model, using team members as a whole as the reference, we expect that in a team context, team personality composition will predict team member (shared) leadership and lead to team outcomes. Thus, in our model team member integrity is conceptualized as an antecedent factor, predicting shared leadership, which leads to team innovation.

Therefore, we expect integrity's effect on team outcomes will be indirect and the mechanism through which integrity will influence team innovation is through its positive effect on shared leadership. By fostering the occurrence of shared leadership, integrity indirectly affects innovation as an outcome of the shared leadership process. Therefore, we propose:
Hypothesis 3b Shared leadership will indirectly influence the relationship between team member integrity and team innovative behavior.

\section{Method Section}

\section{Sample}

Our sample consisted of 43 work teams, comprising 184 team members and their respective team leaders from two different companies. Both samples were involved in product development and training and development in two different organizations. Thus, the tasks comprised complex and cognitive, interdependent knowledge-based work. The team members mean age was 23 years (SD 4.92) and the mean tenure was 1.13 (SD 1.05), team leaders mean age was 30 years (SD 8.90) and mean tenure was 3.46 (SD 2.89). Gender was $89 \%$ male for team member and $98 \%$ male for team leaders.

\section{Measures}

Employees rated shared leadership and their own integrity, and the team leaders rated vertical transformational and empowering leadership and the innovative behavior of their respective teams. The study was part of a larger study on teams. Shared leadership and vertical transformational and empowering leadership were assessed using the short scales by Hoch et al. (2010a; similar: 2010b). We used a direct consensus model (Chan 1998) with the team as a whole as the referent, arguing that this is more accurate and appropriate in addressing the collective nature of our construct as well as the focus on specific leadership behaviors than other approaches (e.g., Carson et al. 2007). Based on the direct consensus model (Chan 1998) identical item statements were adapted to reflect either the team focus ("we do...") of shared leadership or the hierarchical focus ("my supervisor does...") of vertical transformational and empowering leadership. Identical items were used to measure both vertical transformational and empowering and shared leadership.

We computed the overall shared leadership and vertical leadership out of the two dimensions of (1) transformational leadership and (2) empowering leadership. Transformational leadership was measured with six items, representing the following six behaviors of transformational leadership: (a) idealized influence ["My team leader (members) is (are) driven by higher purposes or ideals."], (b) inspirational motivation ["My team leader (members) provides (provide) a clear vision of whom and what our team is."], (c) individualized consideration ["My team leader (members) shows (show) enthusiasm for my efforts."], (d) intellectual stimulation ["My team leader (members) seeks (seek) a broad 
range of perspectives when solving problems."], (e) challenging the status quo ["My team leader (members) encourages (encourage) me to rethink ideas that have never been questioned before."], (f) expecting exceptional performance ["My team leader (members) encourages (encourage) me to go above and beyond what is normally expected of one (e.g., extra effort)."]. Empowering leadership was measured with a total of twelve questions, four items each for individual and team empowering leadership and four items for participative goal setting leadership. Individual empowering leadershipincluded: (a) encouraging independent action ["My team leader (members) encourages (encourage) me to learn new things." "My team leader (members) encourages (encourage) me to search for solutions to my problems without supervision."], (b) encouraging self-development ["My team leader (members) urges (urge) me to assume responsibilities on my own."], and (c) encouraging self-reward ["My team leader (members) encourages (encourage) me to give myself a pat on the back when I meet a new challenge."]. Team empowering leadership was measured with four items. This scale focused on teamwork and assessed whether the external team leader or team members encouraged members to work together as a team, and viewed the team as the means to achieving the group objectives [e.g., "My team leader (members) encourages (encourage) me to work together with other individuals who are part of the team."]. Participation was also measured with four items [e.g., "My team leader (members) decides (decide) on my performance goals together with me."].

Overall, scale reliabilities were .93 for vertical leadership and .91 for shared leadership (Cronbach Alpha, 1951). All items are attached in the Appendix.

Integrity was measured with eight items. The eight items were adapted from Dineen et al. (2006); Peterson and Seligman (2004); Winter and Barenbaum (1985); a complete item list can be obtained from the author. Team members rated their integrity in terms of responsibility and trustworthiness. Two sample items for responsibility are "I keep my promises" and "I can be trusted with confidential information" and trustworthiness "I believe that honesty is the basis for trust" and "I have high moral standards". Results from confirmatory factor analyses documented that while there was a good fit for the two-dimensional factor structure, the one factor structure showed a better fit. Cronbach alpha was .67. Considering the structure of personality traits and the large number of questions necessary to measure personality traits sufficiently, this was considered appropriate.

Innovative behavior was rated by team leaders, with a nine-item scale by Janssen (2000). This scale contained each three items on the three dimensions of: idea generation, idea promotion, and idea realization. Two sample items for idea generation are: "Our team creates new ideas concerning solutions for difficult problems" and "Our team searches out new working methods and techniques." Two sample items for idea promotion are "In our team, we acquire approval for innovative ideas." "In our team, we make each other enthusiastic for innovative ideas." Two items for idea realization are "Our team often implements innovative ideas in the work environment," "After we implement ideas, they evaluate their utility." The Cronbach alpha was .82 .

We computed within-group agreement of all ratings using the rwg index (James et al. 1993). We obtained a mean rwg of .78 for shared leadership, .79 for vertical leadership. Thus, aggregation to the group level for all scales was appropriate. All analyses were performed on the group level. Analyses were performed conducting structural equation modeling (SEM, Arbuckle 2003).

\section{Results}

Means, standard deviations, and correlations are provided in Table 1. To test our hypotheses, we conducted direct and indirect effects tests with model analysis using SEM with AMOS (Arbuckle 2003) adhering to general assumptions (Baron and Kenny 1986; Jung and Avolio 2000; Kenny 1979; Mathieu and Taylor 2006).

As summarized in Fig. 2, shared leadership was a strong predictor of team innovative behavior $(b=.80, p<.01)$. Vertical transformational and empowering leadership significantly predicted shared leadership $(b=.75, p<.001)$ and team member integrity predicted shared leadership ( $b=.77, p<.01)$. Therefore, hypotheses $1,2 \mathrm{a}$, and $3 \mathrm{a}$ were supported. In addition, we found a significant path for the (direct) relationship between vertical transformational and empowering leadership and team innovative behavior $(b=.69, p<.05)$, and a non-significant path between the team member integrity and team innovative behavior, as also displayed in Fig. 2. To test for indirect effects of shared leadership, as hypothesized in hypothesis $2 b$ and $3 b$, we further conducted additional model comparison tests using SEM, where we examined the direct, full effects model (i.e., vertical transformational and empowering leadership and team member integrity as predictors of shared leadership and team innovative behavior, and shared leadership as an antecedent of innovative behavior), and the indirect model, (i.e., vertical transformational and empowering leadership and team member integrity as antecedents of shared leadership), and shared leadership in predicting team innovative behavior. Those results are displayed in Table 2.

With regard to vertical transformational and empowering leadership, we found that the full, direct effects model 
Table 1 Mean scores, standard deviations, and correlations of main study variables

Note $N=43$ teams; $M$ team member rated, $L$ leader rated ${ }^{\mathrm{t}} p<.10, * p<.05$, $* * p<.01, * * * p<.001$ (two-tailed)

\begin{tabular}{lrrrrrrrrr}
\hline & $M$ & SD & 1 & 2 & 3 & 4 & 5 & 6 & 7 \\
\hline Age $^{\mathrm{M}}$ & 22.64 & 7.24 & - & & & & & & \\
Gender $^{\mathrm{M}}$ & 1.11 & .25 & -.15 & - & & & & \\
Group size $^{\mathrm{M}}$ & 4.27 & 3.08 & -.22 & .10 & - & & & \\
Shared leadership $^{\mathrm{M}}$ & 3.28 & .58 & -.18 & .02 & .08 & - & & \\
Vertical transf. and $_{\quad}$ & 3.60 & .21 & .11 & -.02 & -.13 & $.36 *$ & - & \\
$\quad$ empowering leadership $^{\mathrm{L}}$ & & & & & & & & \\
Member integrity $^{\mathrm{M}}$ & 3.46 & .24 & -.05 & .16 & .12 & $.32^{*}$ & -.02 & - \\
Innovative behavior $^{\mathrm{L}}$ & 4.10 & .27 & -.01 & -.21 & -.06 & $.37 *$ & -.08 & .06 & - \\
\hline
\end{tabular}

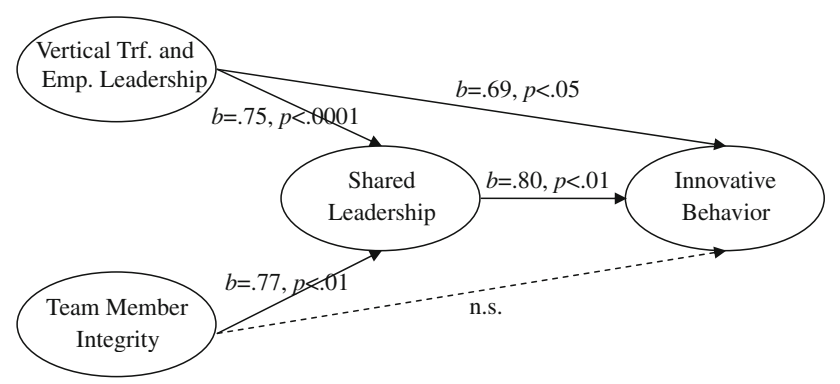

Fig. 2 SEM results on Input-Process-Output Model of Shared Leadership predicting Innovation, Vertical Leadership and Employee Integrity predicting Shared Leadership

(including the paths from vertical transformational and empowering leadership to innovative behavior and integrity to innovative behavior) fit the data very well $\left(\chi^{2}(1)=3.79\right.$, $p=.28, \chi^{2} / d f=1.27, \mathrm{CFI}=.96$, RMSEA $\left.=.07\right)$. However, the indirect model (i.e., without the direct paths from vertical transformational and empowering leadership to innovative behavior and from integrity to innovation) also fitted the data very well $\left(\chi^{2}(3)=4.45, p=.22, \chi^{2} / d f=\right.$ $1.48, \mathrm{CFI}=.94$, RMSEA $=.09)$ and there was no significant difference between this and the full model $\left(\Delta \chi^{2}(2)=\right.$ .67, n.s.). The full effects model did thus not add significant improvement. Thus, based on the procedures delineated, our data supports the occurrence of indirect effects (Mathieu and Taylor 2006), showing that shared leadership functions as a mediator toward the impact of the two antecedents, on team innovative behavior. However, in addition, we also obtained a weak direct effect by vertical transformational and empowering leadership in predicting team innovation, showing that the vertical team leader is not only indirectly, but also directly able to impact team innovation. Thus, hypothesis $2 \mathrm{~b}$ was not supported whereas hypothesis $3 \mathrm{~b}$ received full support.

\section{Discussion}

Based on the basic assumption of input, process output (IPO) models for team processes (Hackman 1987; Illgen et al. 2005; McGrath 1991) our goal was to extend the nomological network (Cronbach and Meehl 1955) on shared leadership. Overall, our results supported our model and demonstrated that both vertical transformational and empowering leadership and team member integrity function as antecedents of shared leadership and that shared leadership is associated with innovative behavior, as rated by the supervisors. Furthermore, vertical transformational and empowering leadership but not team member integrity was directly related to team innovative behavior. Thus, the results demonstrated that shared leadership played a key role in explaining the relationship between team input factors, such as vertical transformational and empowering leadership or team member integrity, and team outcomes, which in this study was team innovative behavior.

In sum, researchers have described innovation as a complex set of behaviors comprising the generation of ideas, referring to the creation of new ideas for improvements and searching out new working methods, techniques, or instruments; idea promotion that involves mobilizing support for innovative ideas and acquiring approval for those ideas; and idea realization that involves transforming innovative ideas into useful applications (Janssen 2000; Kanter 1988; Scott and Bruce 1994). We expected that shared leadership may have a beneficial impact on team innovation for all three of these phases, as it may lead to better quality of shared information leading to higher quality idea generation, subsequent promotion of new ideas among members because of enhanced "power balance" (Pearce et al. 2008), and facilitating the dissemination and implementation of ideas. Our findings clearly supported these assumptions.

We believe that by investigating vertical transformational and empowering leadership and team member integrity as antecedents, and showing that shared leadership is associated with innovative behavior as a team outcome, we were successful in extending the literature on shared leadership. Furthermore, this research builds on arguments by Cox et al. (2003) stating that vertical transformational and empowering leadership and team member 
Table 2 Findings from SEM analyses on main effects and mediated model analyses

\begin{tabular}{|c|c|c|c|c|c|c|c|c|}
\hline & $\chi^{2}$ & $d f$ & $p$ & $\begin{array}{l}\chi^{2} / \\
d f\end{array}$ & CFI & RMSEA & $\Delta \chi^{2}$ & $\Delta d f$ \\
\hline $\begin{array}{l}\text { Full model: vertical trf. and emp. leadership and integrity predicting shared leadership } \\
\text { and innovation, shared leadership predicting innovation }\end{array}$ & 3.79 & 1 & .28 & 1.27 & .96 & .07 & & \\
\hline $\begin{array}{l}\text { Mediated model: vertical trf. and emp. leadership and integrity predicting shared } \\
\text { leadership; shared leadership predicting innovation }\end{array}$ & 4.45 & 3 & .22 & 1.48 & .94 & .09 & 2 & .67 \\
\hline $\begin{array}{l}\text { Mediation step 1: vertical trf. and emp. leadership and integrity predicting shared } \\
\text { leadership and innovative behavior }\end{array}$ & 15.54 & 4 & .01 & 3.88 & .49 & .22 & 3 & 11.75 \\
\hline $\begin{array}{l}\text { Mediation step 2: vertical trf. and emp. leadership, integrity and shared leadership } \\
\text { predicting innovative behavior }\end{array}$ & 7.84 & 5 & .001 & 4.08 & .33 & .23 & 4 & 3.39 \\
\hline
\end{tabular}

Note $N=43$ teams, $* * * p<.001, * * p<.01, * p<.05$

personality team composition represent important antecedents of shared leadership. Hence, our findings show that it is not so much the direct effects of vertical transformational and empowering leadership or team member integrity that affect the team outcomes. Rather it is that shared leadership indirectly effects innovative behavior, and therefore our research points out once more the strong impact that shared leadership has on team outcomes. Consequently, the study found that shared leadership represents an important indirect effects variable in an IPO model or nomological net or framework on shared leadership.

In addition, our results also contribute to the literature on innovative behavior, which is crucial for today's organizations, considering the increasingly competitive and fast changing environment. We found that shared leadership had a significant and positive impact on team innovative behavior. Vertical transformational and empowering leadership contributed directly and indirectly and team integrity contributed indirectly to the occurrence innovation, and both contributed directly to the occurrence of shared leadership, which was directly associated with team innovative behavior. This suggests a stepwise process.

One possible mitigating variable in this relationship is the time needed for team members to develop their shared leadership skills, which is a factor that could be examined by future researchers. In other words, research on innovative behavior and shared leadership might benefit from an investigation of the impact of time and project phases, or stages of team process development and the time needed to form intra-team shared leadership competencies. Another research need is to investigate other possible outcomes of shared leadership in addition to performance and innovative behavior to extend research on shared leadership; possibilities include employees' health, satisfaction, OCBs, and commitment.

Next, our results extend research on vertical leadership. Precisely, previous researchers have examined vertical transformational and empowering leadership with regard to team processes and team outcomes, and researchers have also discussed vertical transformational and empowering leadership as a possible antecedent of shared leadership (e.g., Pearce et al. 2008) and innovation (Huelsheger et al. 2009). However, up to this research, the impact of vertical transformational and empowering leadership on shared leadership had not yet been empirically examined. In our study, however, we found that vertical transformational and empowering leadership influences shared leadership development and we report empirical support for the expected indirect effect of shared leadership on the vertical transformational and empowering leadership and team innovative behavior relationship. Our results suggest that future research should investigate the impact of vertical transformational and empowering leadership on teamrelated processes such as collective self-efficacy, group potency, etc. (Bass et al. 2003), or other possible process factors within the organization such as empowerment or HR structures (Zhu et al. 2005). While we find evidence for both direct and indirect effects, future research is also needed that examines the differential impact of other forms of vertical leadership (e.g., goal setting, ethical leadership, etc.) on team outcomes and innovation. This would further extend current research indicating that vertical leadership is associated with shared leadership as well as which vertical leadership dimensions are more or less important in influencing the occurrence of shared leadership and other team related processes, such as innovation.

Finally, our study extends prior literature on integrity as a personality disposition of team members, as we found team member integrity to be an important antecedent of shared leadership, and therefore this contributes to the IPO model literature (Hackman 1987; Illgen et al. 2005; Kozlowski and Bell 2003). Team members, who are more reliable, trust their fellow team members, and have a tendency to behave more ethically, fair and in a transparent manner, are more likely to be associated with the occurrence of shared leadership. Thus, our research contributes to prior literature on leadership (De Hoogh et al. 2005; 
Palanski and Yammarino 2007; Spangler and House 1991) and team composition (Barrick et al. 2001; Bell 2007; Stewart 2006) by showing that integrity, as a personality disposition, is associated with shared leadership. Future research could extend this by measuring additional personality dimensions of team members and by investigating whether there is some kind of "team player" personality facet that exists that can facilitate the occurrence of shared leadership.

\section{Limitations}

Regarding limitations of this research, several things should be noted. First, this study was based on cross-sectional data and therefore, as with cross-sectional data in general, this precludes determination of causality. Second, our sample of 43 work teams, comprising 184 team members and their leaders was largely male ( $89 \%$ for team; $98 \%$ for team leaders). Further limitations include a broad measure of leadership (both vertical transformational and empowering and shared) based on multiple approaches to leadership, as well as the use of only one personality variable, and one approach to team composition using this personality variable. Together, while our investigation has explored the impact of vertical transformational and empowering leadership and team integrity on shared leadership, and shared leadership and its association with innovative behavior, it simply represents a first step, and we encourage future researchers to conduct longitudinal studies of these relationships. Precisely, we encourage future researchers to examine other personality variables and more differentiated leadership measures, as well as to replicate our results in longitudinal settings and in teams that are more gender diverse. Also, results could be replicated with regard to longitudinal and cross-sectional data, with project work teams that comprise different work forms and settings, exceeding those of the present investigation. Also, the process measures such as information sharing or shared mental models (SMM), which I have discussed as possible explanatory mechanisms, have not directly been evaluated. This exceeds the scope of the present model. Clearly, future research would have to investigate this.

\section{Implications}

The implications of this research are straightforward. First, in selecting members for team-based work structures, our results suggest that integrity should be considered as selection criteria (Ones et al. 1993). Second, organizations that want to promote shared leadership (Carson et al. 2007; Pearce et al. 2008) should train their leaders in vertical transformational and empowering leadership behaviors that promoted shared leadership in teams. Third, where innovative behavior is an organizational objective for team performance, companies should promote shared leadership as an approach for managing those teams. This could be accomplished through training as well as assignment of team member roles, where each member is given responsibility and make accountable for team decision making and leading each other.

\section{Conclusion}

We found that vertical transformational and empowering leadership and integrity enhanced shared leadership, which was associated with team innovative behavior. Furthermore, our results indicated that vertical transformational and empowering leadership directly and indirectly, and integrity indirectly impacted team innovative behavior, and their associations with innovative behavior were explained by shared leadership. In sum, the study highlights the importance of shared leadership in team functioning and its relation to team outcomes. Together, the results underscore the value of devoting further research attention to shared leadership, antecedents and outcomes of shared leadership, and the indirect role shared leadership plays in contributing to important organizational outcomes such as innovative behavior.

\section{Appendix}

- Vertical transformational and empowering leadership (Cronbach alpha .93)

(A) Transformational leadership:

"My team leader provides a clear vision of whom and what our team is."

"My team leader is driven by higher purposes or ideals."

"My team leader shows enthusiasm for my efforts."

"My team leader encourages me to rethink ideas which had never been questioned before."

"My team leader seeks a broad range of perspectives when solving problems."

"My team leader encourages me to go above and beyond what is expected (e.g., extra effort)."

(B) Individual empowering leadership:

"My team leader encourages me to search for solutions to my problems without supervision." 
"My team leader urges me to assume responsibilities on my own."

"My team leader encourages me to learn new things."

"My team leader encourages me to give myself a pat on the back when I meet a new challenge."

(C) Team empowering leadership:

"My team leader encourages me to work together with the others who are part of the team."

"My team leader advises me to coordinate my efforts with the others who are part of the team."

"My team leader urges me to work as a team with other individuals who are part of the team."

"My team leader expects that the collaboration with the other members in the team works well."

(D) Participative leadership:

"My team leader decides on my performance goals together with me."

"My team leader and I work together to decide what my performance goals should be."

"My team leader and I sit down together and reach agreement on my performance goals."

"My team leader work with me to develop my performance goals."

- Shared leadership (Cronbach alpha .91)

(A) Transformational leadership:

"My colleagues provide a clear vision of whom and what our team is."

"My colleagues are driven by higher purposes or ideals."

"My colleagues show enthusiasm for my efforts."

"My colleagues encourage me to rethink ideas which had never been questioned before."

"My colleagues seek a broad range of perspectives when solving problems."

"My colleagues encourage me to go above and beyond what is normally (e.g., extra effort)."

(B) Individual empowering leadership:

"My colleagues encourage me to search for solutions to my problems without supervision." "My colleagues urge me to assume responsibilities on my own."

"My colleagues encourage me to learn new things."
"My colleagues encourage me to give myself a pat on the back when I meet a new challenge."

(C) Team empowering leadership:

"My colleagues encourage me to work together with other individuals who are part of the team." "My colleagues advise me to coordinate my efforts with the others, who are part of the team." "My colleagues urge me to work as a team with the others, who are part of the team."

"My colleagues expect that the collaboration with the other members in the team works well."

(D) Participative leadership:

"My colleagues decide on my performance goals together with me."

"My colleagues and I work together to decide what my performance goals should be."

"My colleagues and I sit down together and reach agreement on my performance goals."

"My colleagues work with me to develop my performance goals."

- Integrity (Cronbach alpha .67)

(A) Social responsibility (4 items):

"I keep my promises."

"I can be trusted with confidential information."

(B) Trustworthiness (4 items):

"I believe that honesty is the basis for trust." "I have high moral standards."

- Innovation (Cronach alpha. 82)

(A) Idea generation (3 items):

"Our team creates new ideas concerning solutions for difficult problems."

"Our team searches out new working methods and techniques."

(B) Idea promotion (3 items):

"In our team, we acquire approval for innovative ideas,"

"In our team, we make each other enthusiastic for innovative ideas,"

(C) Idea realization (3 items):

"Our team often implements innovative ideas in the work environment,"

"After we implement ideas, they evaluate their utility." 


\section{References}

Amabile, T. M. (1988). A model of creativity and innovation in organizations. In B. M. Staw \& L. L. Cummings (Eds.), Research in organizational behavior (Vol. 10, pp. 187-209). Greenwich, CT: JAI Press.

Amabile, T. M. (1996). Creativity in context. Boulder, CO: Westview Press.

Amabile, T. M., Schatzel, E. A., Moneta, G. B., \& Kramer, S. J. (2004). Leader behaviors, perceived, leader support, and subordinate creativity. The Leadership Quarterly, 15, 5-32.

Ancona, D. G., \& Caldwell, D. F. (1992). Bridging the boundary: External process and performance in organizational teams. Administrative Science Quarterly, 37, 634-665.

Arbuckle, J. L. (2003). AMOS 5.0 [Computerprogramm].Chicago: Smallwaters.

Balkin, D. B., Tremblay, M., \& Westerman, J. (2001). Workplace innovations in large, unionized Canadian organizations. Journal of Business and Psychology, 15, 439-448.

Bandura, A. (1997). Self-efficacy: The exercise of control. New York: Freeman.

Baron, R. M., \& Kenny, D. A. (1986). The moderator-mediator variable distinction in social psychological research: Conceptual, strategic, and statistical considerations. Journal of Personality and Social Psychology, 51, 1173-1182.

Barrick, M. R., Mount, M. K., \& Judge, T. A. (2001). Personality and performance at the beginning of the new millennium: What do we know and where do we go next? International Journal of Selection \& Assessment, 9, 9-30.

Barrick, M. R., Stewart, G. L., Neubert, M. J., \& Mount, M. K. (1998). Relating member ability and personality to work-team processes and team effectiveness. Journal of Applied Psychology, 83, 377-391.

Bass, B. M., Avolio, B. J., Jung, D. I., \& Berson, Y. (2003). Predicting unit performance by assessing transformational and transactional leadership. Journal of Applied Psychology, 88, 207-218.

Bell, S. T. (2007). Deep-level composition variables as predictors of team performance: A meta-analysis. Journal of Applied Psychology, 92, 595-615.

Carson, J. B., Tesluk, P. E., \& Marrone, J. A. (2007). Shared leadership in teams: An investigation of antecedent conditions and performance. Academy of Management Journal, 50, 1217-1234.

Chan, D. (1998). Functional relations among constructs in the same content domain at different levels of analysis: A typology of composition models. Journal of Applied Psychology, 83, 234-246.

Choi, J. N., \& Chang, J. Y. (2009). Innovation implementation in the public sector: An integration of institutional and collective dynamics. Journal of Applied Psychology, 94, 245-253.

Chou, L.-F., Wang, A.-C., Wang, T.-Y., Huang, M.-P., \& Cheng, B.S. (2008). Shared work values and team member effectiveness: The mediation of trustfulness and trustworthiness. Human Relations, 61, 1713-1742.

Cox, J. F., Pearce, C. L., \& Perry, M. (2003). Toward a model of shared leadership and distributed influence in the innovation process: How shared leadership can enhance new product development team dynamics and effectiveness. In C. L. Pearce \& J. A. Conger (Eds.), Shared leadership: Reframing the How's and Whys of leadership (pp. 48-68). Thousand Oaks, CA: SAGE.

Cronbach, L. J. (1951). Coefficient alpha and the internal structure of tests. Psychometrika, 16, 297-334.

Cronbach, L., \& Meehl, P. (1955). Construct validity in psychological tests. Psychological Bulletin, 52, 281-302.
Currie, G., \& Lockett, A. (2007). A critique of transformational leadership: Moral, professional and contingent dimensions of leadership within public services organizations. Human Relations, 60, 341-370.

Currie, G., Lockett, A., \& Suhomlinova, O. (2009). The institutionalization of distributed leadership: A 'Catch-22' in English public services. Human Relations, 62, 1735-1761.

Day, D. V., Gronn, P., \& Salas, E. (2004). Leadership capacity in teams. The Leadership Quarterly, 15, 857-880.

De Cremer, D., \& van Knippenberg, D. (2002). How do leaders promote cooperation? The effects of charisma and procedural fairness. Journal of Applied Psychology, 87, 858-866.

De Hoogh, A. H. B., \& Den Hartog, D. N. (2008). Ethical and despotic leadership, relationships with leader's social responsibility, top management team effectiveness and subordinates' optimism: A multi-method study. Leadership Quarterly, 19, 297-311.

De Hoogh, A. H. B., Den Hartog, D. N., Koopman, P. L., Thierry, H., Van den Berg, P. T., Van der Weide, J. G., et al. (2005). Leader motives, charismatic leadership, and subordinates' work attitude in the profit and voluntary sector. The Leadership Quarterly, 16, 17-38.

Dineen, B. R., Tomlinson, E. C., \& Lewicki, R. J. (2006). Supervisory guidance and behavioral integrity: Relationships with employee citizenship and deviant behavior. Journal of Applied Psychology, 91, 622-635.

Edmondson, A. (1999). Psychological safety and learning behavior in work teams. Administrative Science Quarterly, 4, 350-383.

Ensley, M. D., Hmieleski, K. M., \& Pearce, C. L. (2006). The importance of vertical and shared leadership within new venture top management teams: Implications for the performance of startups. Leadership Quarterly, 17, 217-231.

Ensley, M.D., Pearson, A., \& Pearce, C. L. (2003). Top management team process, shared leadership, and new venture performance: A theoretical model and research agenda. Human Resources Management Review, 13, 329-346.

Fry, L., \& Kriger, M. (2009). Towards a theory of being-centered leadership: Multiple levels of being as context for effective leadership. Human Relations, 62, 1667-1696.

Garcia-Mortales, V. J., Matias-Reche, F., \& Hurtado-Torres, N. (2008). Influence of transformational leadership on organizational innovation and performance depending on the level of organizational learning in the pharmaceutical sector. Journal of Organizational Change Management, 21, 188-212.

Gibb, C. A. (Ed.). (1954). Leadership (Vol. 2). Reading, MA: Addison-Wesley.

Guzzo, R. A., Yost, P. R., Campbell, R. J., \& Shea, G. P. (1993). Potency in groups: Articulating a construct. British Journal of Social Psychology, 32, 87-106.

Hackman, J. R. (1987). The design of work teams. In J. Lorsch (Ed.), Handbook of organizational behavior (pp. 315-342). Englewood Cliffs, NJ: Prentice-Hall.

Harrison, D. A., \& Klein, K. J. (2007). What's the difference? Diversity constructs as separation, variety, or disparity in organizations. Academy of Management Review, 32, 1199-1228.

Hmieleski, K. M., Cole, M. S., \& Baron, R. A. (2012). Shared authentic leadership and new venture performance. Journal of Management. doi:10.1177/0149206311415419.

Hoch, J. E., Pearce, C. L., \& Dulebohn, J. (2010a). Shared leadership questionnaire (SLQ): Developing a short scale to measure shared and vertical leadership in teams. SIOP Conference (Visual Presentation), Atlanta, USA.

Hoch, J. E., Welzel, L., \& Pearce, C. L. (2010b). The most effective team leadership is shared: The impact of shared leadership, diversity, and coordination on team performance. Journal of Personnel Psychology, 9, 105-116. 
Hogan, R., Curphy, G. J., \& Hogan, J. (1994). What we know about leadership. American Psychologist, 49, 493-504.

House, R. J., \& Baetz, M. L. (1979). Leadership: Some empirical generalizations and new research directions. Research in Organizational Behavior, 1, 341-423.

Huelsheger, U. R., Salgado, J. F., \& Anderson, N. (2009). Team-level predictors of innovation at work: A comprehensive metaanalysis spanning three decades of research. Journal of Applied Psychology, 94, 1128-1145.

Hunter, S. T., \& Cushenbery, L. (2011). Leading for innovation: Direct and indirect influences. Advances in Developing Human Resources, 13, 248-263.

Illgen, D. R., Hollenbeck, J. R., Johnson, B. T., \& Jundt, D. (2005). Teams in organizations: From I-P-O models to IMOI models. Annual Review of Psychology, 56, 517-544.

James, L. R., Demaree, R. G., \& Wolf, D. (1993). $\mathrm{r}_{\mathrm{wg}}$ : An assessment of within-group interrater agreement. Journal of Applied Psychology, 78, 306-309.

Janssen, O. (2000). Job demands, perceptions of effort-reward fairness and innovative work behaviour. Journal of Occupational \& Organizational Psychology, 73, 287-302.

Janssen, O., van de Vliert, E., \& West, M. (2004). The bright and the dark sides of individual and group innovation: A special issue introduction. Journal of Organizational Behavior, 25, 129-145.

Jung, D. I., \& Avolio, B. J. (2000). Opening the black box: An experimental investigation of the mediating effects of trust and value congruence on transformational and transactional leadership. Journal of Organizational Behavior, 21, 949-964.

Jung, D. I., Chow, C., \& Wu, A. (2003). The role of transformational leadership in enhancing organizational innovation: Hypotheses and some preliminary findings. The Leadership Quarterly, 14, $525-544$.

Kanter, R. M. (1988). When a thousand flowers bloom: Structural, collective and social conditions for innovation in organization. In B. M. Staw \& L. L. Cummings (Eds.), Research in organizational behavior (Vol. 10, pp. 169-211). Greenwich, CT: JAI Press.

Karau, S. J., \& Williams, K. D. (1993). Social loafing: A metaanalytic review and theoretical integration. Journal of Personality and Social Psychology, 65(4), 681-706.

Kenny, D. (1979). Correlation and causation. New York: Wiley.

Kirkman, B. L., Rosen, B., Tesluk, P. E., \& Gibson, C. B. (2004). The impact of team empowering on virtual team performance: The moderating role of face-to-face-interaction. Academy of Management Journal, 47, 175-192.

Kouzes, J. M., \& Posner, B. Z. (2009). To lead, create a shared vision. Harvard Business Review, 87, 20-21.

Kozlowski, S. W. J., \& Bell, B. S. (2003). Work groups and teams in organizations. In W. C. Borman, D. R. Ilgen, \& R. J. Klimoski (Eds.), Comprehensive handbook of psychology: Industrial and organizational psychology (Vol. 12, pp. 333-375). New York: Wiley.

Liden, R., \& Antonakis, J. (2009). Considering context in psychological leadership research. Human Relations, 62, 1587-1605.

Manz, C. C. (1986). Self-leadership: Toward an expanded theory of self-influence processes in organizations. Academy of Management Review, 11, 585-600.

Manz, C. C., \& Sims, H. P. S. (1987). Leading workers to lead themselves: The external leadership of self-managing work teams. Administrative Science Quarterly, 32, 106-128.

Manz, C. C., \& Sims, H. P., Jr. (1991). Superleadership: Beyond the myth of heroic leadership. Organizational Dynamics, 19, 18-35.

Mathieu, J. E., \& Taylor, S. R. (2006). Clarifying conditions and decision points for mediational type inferences in Organizational Behavior. Journal of Organizational Behavior, 27, 1031-1056.
Mayo, M., Meindl, J. R., \& Pastor, J.-C. (2003). Shared leadership in work teams. In C. L. Pearce \& J. A. Conger (Eds.), Shared leadership: reframing the how's and why's of leadership (pp. 193-214). Thousand Oaks, CA: SAGE.

McClelland, D. C. (1985). How motives, skills, and values determine what people do. American Psychologist, 40, 812-825.

McClelland, D. C., \& Boyatzis, R. (1982). Leadership motive pattern and long-term succession management. Journal of Applied Psychology, 67, 737-743.

McClelland, D. C., \& Burnham, D. H. (1976). Power is the great motivator. Harvard Business Review, 54, 100-110.

McClelland, D. C., \& Burnham, D. (2003). Power is the great motivator. Harvard Business Review, 81, 117-123.

McGrath, J. E. (1991). Time, interaction, and performance (TIP). Small Group Research, 22, 128-147.

Mehra, A., Smith, B. R., Dixon, A. L., \& Robertson, B. (2006). Distributed leadership in teams: The network of leadership perceptions and team performance. Leadership Quarterly, 17, 232-245.

Morgeson, F. P., DeRue, D. S., \& Karam, E. P. (2010). Leadership in teams: A functional approach to understanding leadership structures and processes. Journal of Management, 36, 5-39.

Mumford, M. D. (2000). Managing creative people: Strategies and tactics for innovation. Human Resource Management Review, $10,313-351$.

Neck, C. P., \& Houghton, J. D. (2006). Two decades of selfleadership theory and research: Past developments, present trends, and future possibilities. Journal of Managerial Psychology, 21, 270-295.

Neubert, M. J., \& Taggar, S. (2004). Pathways to informal leadership: The moderating role of gender on the relationship of individual differences and team member network centrality to informal leadership emergence. Leadership Quarterly, 15, 175.

Ones, D. S., Viswesvaran, C., \& Schmidt, F. L. (1993). Meta-analysis of integrity tests validities. Journal of Applied Psychology, 78, 679-693.

Palanski, M. E., \& Yammarino, F. J. (2007). Integrity and leadership: Clearing the conceptual confusion. European Management Journal, 25, 171-184.

Pearce, C. L. (2004). The future of leadership: Combining vertical and shared leadership to transform knowledge work. Academy of Management Executive, 18, 47-57.

Pearce, C. L., \& Conger, J. A. (Eds.). (2003). Shared leadership: Reframing the hows and whys of leadership. Thousand Oaks, CA: SAGE.

Pearce, C. L., \& Manz, C. C. (2005). The new silver bullets of leadership: The importance of self and shared leadership in knowledge work. Organizational Dynamics, 34, 130-140.

Pearce, C. L., Manz, C. C., \& Sims, H. P. (2008). The roles of vertical and shared leadership in the enactment of executive corruption: Implications for research and practice. Leadership Quarterly, 19, 353-359.

Pearce, C. L., \& Sims, H. P., Jr. (2000). Shared leadership: Toward a multi-level theory of leadership. Advances in the Interdisciplinary Studies of Work Teams, 7, 115-139.

Pearce, C. L., \& Sims, H. P., Jr. (2002). Vertical versus shared leadership as predictors of the effectiveness of change management teams: An examination of aversive, directive, transactional, transformational, and empowering leader behaviors. Group Dynamics: Theory, Research, and Practice, 6, 172-197.

Pearce, C. L., Yoo, Y., \& Alavi, M. (2004). Leadership, social work and virtual teams: The relative influence of vertical versus shared leadership in the nonprofit sector. In R. E. Riggio, S. Smith-Orr, \& J. Shakely (Eds.), Improving leadership in nonprofit organizations (pp. 180-204). San Francisco: Jossey-Bass. 
Peterson, C., \& Seligman, M. E. P. (2004). Character strengths and virtues: A classification and handbook. New York, Washington, DC: Oxford University Press, American Psychological Association.

Piccolo, R. F., \& Colquitt, J. A. (2006). Transformational leadership and job behaviors: The mediating role of core job characteristics. Academy of Management Journal, 49, 327-340.

Pillai, R., \& Williams, E. A. (2004). Transformational leadership, self-efficacy, group cohesiveness, commitment, and performance. Journal of Organizational Change Management, 17, 144-159.

Schippers, M. C., Den Hartog, D., \& van Knippenberg, D. (2008). The role of transformational leadership in enhancing team reflexivity. Human Relations, 61, 1593-1616.

Scott, S. G., \& Bruce, R. A. (1994). Determinants of innovative behavior: A path model of individual innovation in the workplace. Academy of Management Journal, 37, 580-607.

Shin, S. J., \& Zhou, J. (2003). Transformational leadership, conservation and creativity: Evidence from Korea. Academy of Management Journal, 46, 703-714.

Solansky, S. T. (2008). Leadership style and team processes in selfmanaged teams. Journal of Leadership \& Organizational Studies, 14, 332-341.

Spangler, W. D., \& House, R. J. (1991). Presidential effectiveness and the leadership motive profile. Journal of Personality and Social Psychology, 60, 439-455.

Spreitzer, G. M., De Janasz, S. C., \& Quinn, R. E. (1999). Empowered to lead: The role of psychological empowerment in leadership. Journal of Organizational Behavior, 20, 511-526.

Stewart, G. L. (2006). A meta-analytic review of relationships between team design features and team performance. Journal of Management, 32, 29-54.

Stewart, A., \& Manz, C. C. (1995). Leadership for self-managing work teams: A typology and integrative model. Human Relations, 48, 747-770.

Taggar, S., Hackett, R., \& Saha, S. (1999). Leadership emergence in autonomous work teams: Antecedents and outcomes. Personnel Psychology, 52, 899-926.
Van der Vegt, G., \& Janssen, O. (2003). Joint impact of interdependency and group diversity on innovation. Journal of Management, 29, 729-751.

Van Iddekinge, C. H., Roth, P. L., Raymark, P. H., \& Odle-Dusseau, H. N. (2011). The criterion-related validity of integrity tests: An updated meta-analysis. Journal of Applied Psychology. doi: 10.1037/a0021196.

Veroff, J., \& Veroff, J. B. (1972). Reconsideration of a measure of power motivation. Psychological Bulletin, 78, 279-291.

West, M. A. (1990). The social psychology of innovation in groups. In M. A. West \& J. L. Farr (Eds.), Innovation and creativity at work (S. 309-333). Chichester: Wiley.

West, M. A., \& Farr, J. L. (1989). Innovation at work: Psychological perspective. Social Behavior, 4, 15-30.

Winter, D. G. (1973). The power motive. New York: Free Press. xix, $373 \mathrm{pp}$.

Winter, D. G. (2007). The role of motivation, responsibility, and integrative complexity in crisis escalation: Comparative studies of war and peace crises. Journal of Personality and Social Psychology, 92, 920-937.

Winter, D. G., \& Barenbaum, N. B. (1985). Responsibility and the power motive in women and men. Journal of Personality, 53, 335-355.

Witt, L. A., Burke, L. A., Barrick, M. A., \& Mount, M. K. (2002). The interactive effects of conscientiousness and agreeableness on job performance. Journal of Applied Psychology, 87, 164-169.

Woodman, R. W., Sawyer, J. E., \& Griffith, R. W. (1993). Toward a theory of organizational creativity. Academy of Management Review, 18, 293-321.

Zhu, W., Chew, I. K. H., \& Spangler, W. D. (2005). CEO transformational leadership and organizational outcomes: The mediating role of human-capital-enhancing human resource management. The Leadership Quarterly, 16, 39-52. 